\title{
アマルガムの還元作用に就て（第二報） アマルガム表面に關する一所見
}

(昭和八年八月十一日受領＼cjkstart昭利八年十月廿五日印剧)

益苦良

\section{（I）緒言}

前報に於て含硫酸三價鐵溶液に對する亞鉛アマルガム（以後 Zn-Hg と記す）の還元作用に關し， (i) $\mathrm{Zn}-\mathrm{Hg}$ の $\mathrm{Zn}$ 濃度小なる程, 其の還元能は堵大し, (ii) 被還元溶液の酸度の小るる程，其の還元 能は助長せらるて5喑示的事鿓を得たるを報告せり．よつて著者は之が䦣明のため，貝驗を逐行

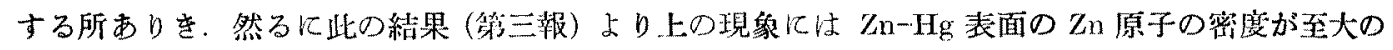

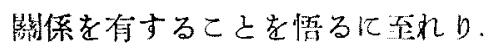

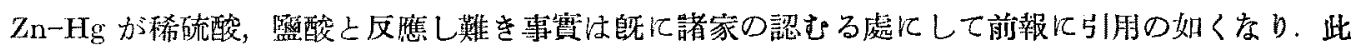
の反應し難しと言ふは如何なる程度のるのなるか？Zn-Hg が酸性溶液と接觸 (兩相靜止) せる界面

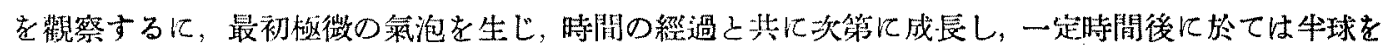

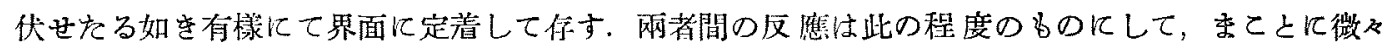
たるのみ，諸家の認めし處も恐らく斯の如をものなりしなるへし. 然るに著者は $\mathrm{Zn}-\mathrm{Hg}$ が酸性溶液

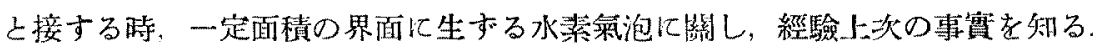

(i) Zn-Hg $\mathrm{Znn}$ 濃度大なる程，氣泡の數多し.

(ii）溶液の酸度大なる程，又室溫高さ程，氣泡の數多く，且つ其の成長速かなり.

從來，アマルガムと酸との反應の研究されたる例さまで多からず. W. Fraenkel ${ }^{1)}$ 及び H. Heiz 爾

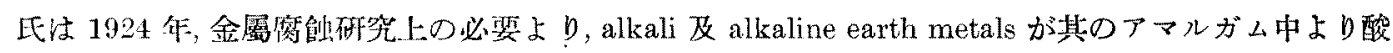
一の溶解速度發生する水素量によりて测定せり。此際は反應系は攪拌を行ひ，其の結果として反 應速度恒數は alkaline earth amalgamsの場合は水素イオン漂度により亦アマルガム中 metal の濖度 によりて子變化するとせり，上の一人 W. Fraenkel ${ }^{2)}$ は更に 1928 年に E. Wengel 及び L. Cahn 氏 等之共沉 alkali 及 alkaline earth 其他金屬ア、ルガム之酸之の反應に就て研究せ り. 此の場合も反應

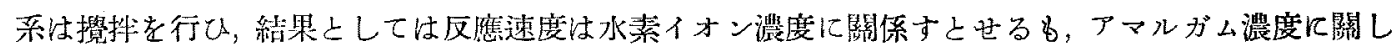

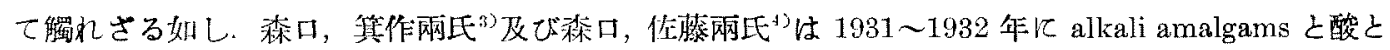

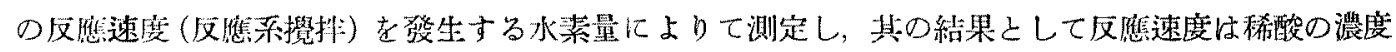

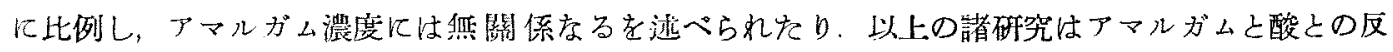

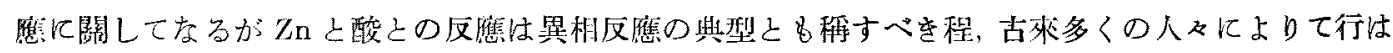

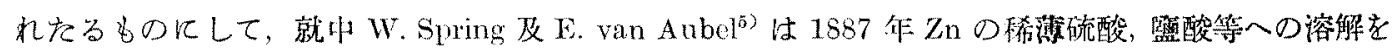

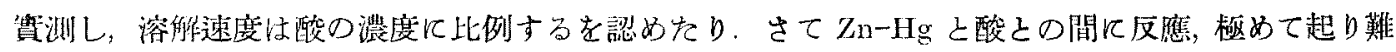
しとするも, 何微少ながら起るべを反碓の傾向が酸の嶩度に對して關係を持つべき事は, 前項引用の 偝研究の絬非上り見るも，之を想像するに難からず。

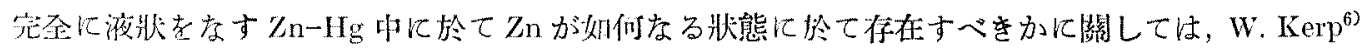

1) Z. anorg. allgem. Chem., 133 (1924), 153.

2) ibid., $171(1928), 82$.

3) 本誌, 52 (1931), 425 .

4) 本热, $53(1982), 708$.

5) Z. Phys. Chem., 1 (1887), 406.

6) Z. anorg. Chem., 25 (1900), 54. 


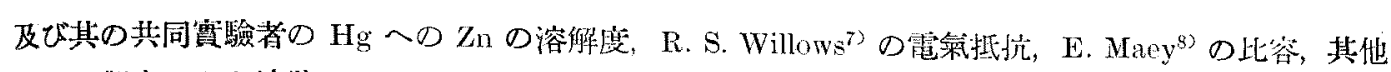
種々の觀察により液㷋 $\mathrm{Zn}-\mathrm{Hg}$ 中には一定の化合物の存在せざること確められをる處なれば，Zn は

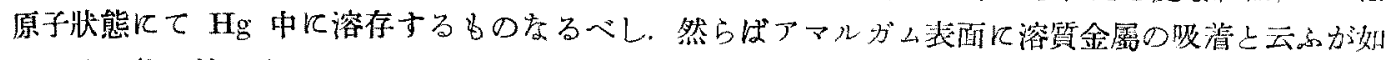

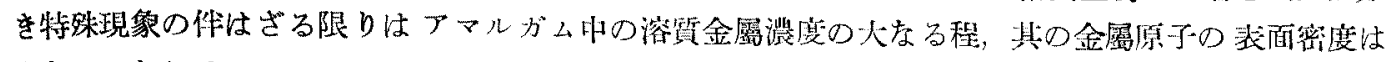

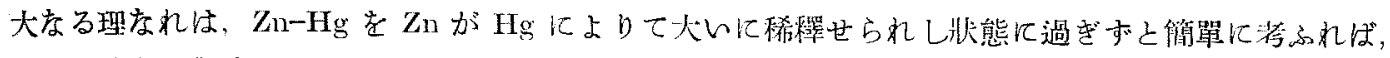

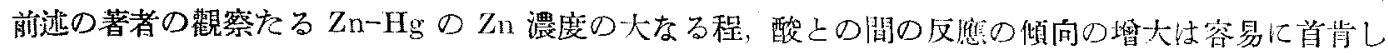

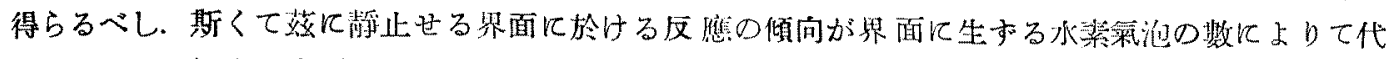
表せらるとの假定を容認せば，上の（i）の事項は常然の結果過ぎさることとなる。そもそもアマル がム中の溶質金屬の濃 度に直接閭係せる其の金屬原子の表面密黀上は如何なるものか，從來斯くの

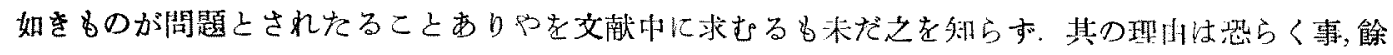

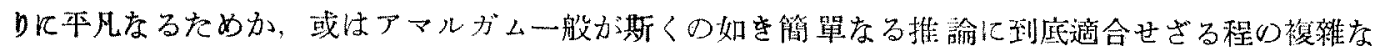

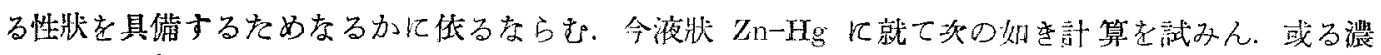

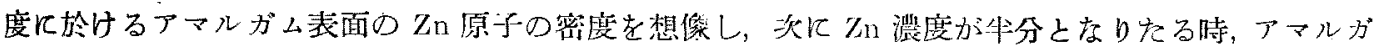

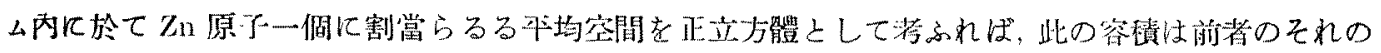

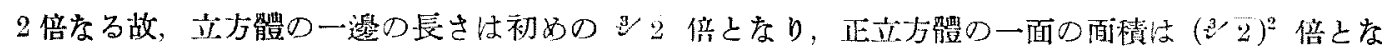
る. 逆飞單位面積中の Zn 原子數は $1: 1 /(2 / 2)^{2}=1: 0.63$ の比となる.アマルガム表面江於ても此の 比率は變ぜざるを以て，一般汇溶質金屬の浱度が或る場合の $1 / n$ となれば其の原于の表面密度は

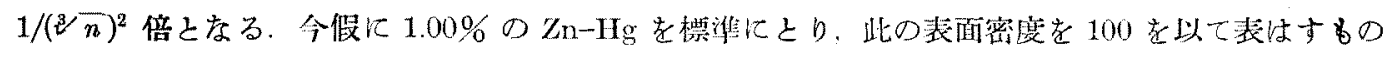

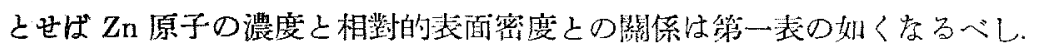

\begin{tabular}{|c|c|c|c|c|c|c|}
\hline $7 \mu$ & 震 & 度 & 相對的表面淧位 & $\mathrm{Z}_{\mathrm{n}}$ & 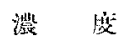 & 相對的表面密度 \\
\hline & $\begin{array}{r}\% \\
2.00\end{array}$ & & 158.7 & & $\begin{array}{r}\% \\
0.10\end{array}$ & 21.6 \\
\hline & 1.00 & & 100 & & 0.05 & 13.6 \\
\hline & 0.50 & & 63.0 & & 0.02 & 7.4 \\
\hline & 0.20 & & 34.2 & & 0.01 & 4.6 \\
\hline
\end{tabular}

さて前項 (i) 所述几關し, 界面の氣泡數が反應の傾向の大小を代裴するものとする假定を設くれば, 一定條件に於て各濃度の Zn-Hg D一定面積の界面に生和る氣泡數の比率は前記 Zn 原子の相数的

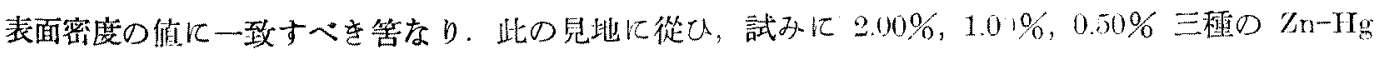

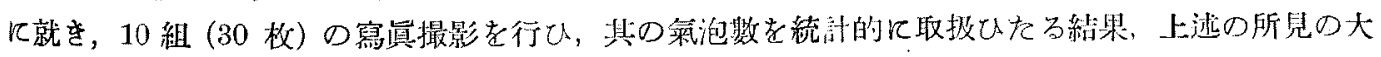
體；誤らざるを確め得をり，低りて妙に之を報告せんと欲する次第なり。

\section{(II) 實醶と其の結果}

[甲] $\mathrm{Zn}-\mathrm{Hg}$ の作製

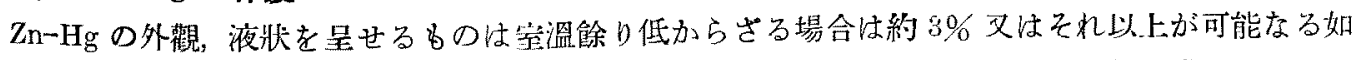

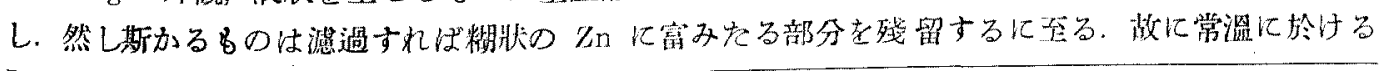

7) Phil. Mag., (5), 48 (1899), 447.

8) Z. Phys. Chem., $50(1900), 212$. 


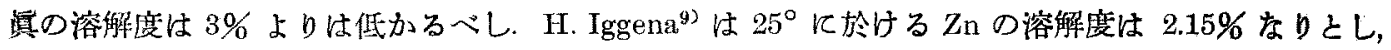
J. L. Crenshaw ${ }^{10\rangle}$ は同じく $25^{\circ}$ に於て Hg $100 \mathrm{~g}$ に就を Zn $2.2199 \mathrm{~g}$ なりせる故，之を\%に換算

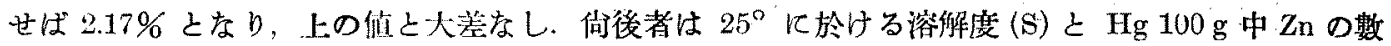

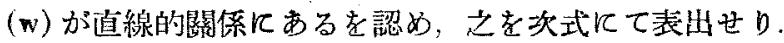

$$
\mathrm{S}=13.5340-0.0859 \mathrm{w}
$$

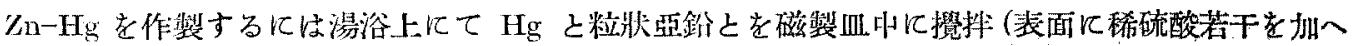
以て酸化老防ぐ)せば $0.5 \sim 1$ 時間飞て得らる. 著者は $2.00 \%, 1.00 \%, 0.50 \%, 0.20 \%, 0.10 \% の 5$ 種

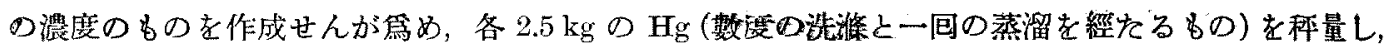

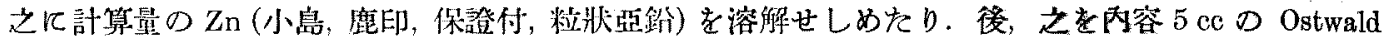
型比重計三個を以て $25^{\circ}$ に於ける比重を測定し（偩空補正を加ふ. 純 $\mathrm{Hg}$ の比重として 13.53395

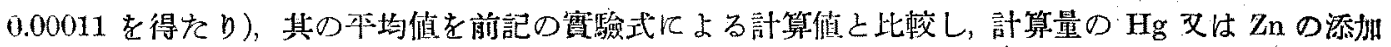
によりて補正したり。本研觉に於ては以後上の加く作成せるbのを一部分づ使用し, 最後に比重

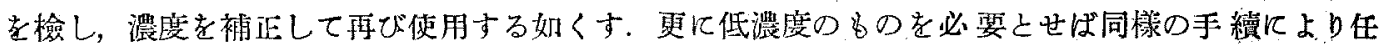
意作成せんとす。

\section{[乙] 界面氣泡の撮影}

圖の如を硝子器三個に夫ぬ $2.00 \%, 1.00 \%, 0.50 \% の \mathrm{Zn-Hg}$ を器の高さの牛まで入れ，濾紙を以

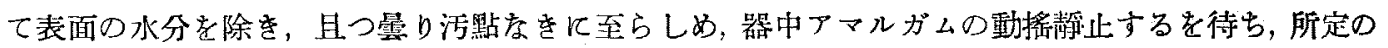

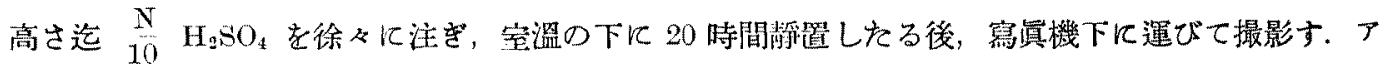
マルガム表面の周邊壮下方に彎曲せるねめ，此の部分は細微氣 泡密集し，中心上り牛徑約 $1.7 \sim 1.8 \mathrm{~cm}$ 以内儿於て氣泡口分布

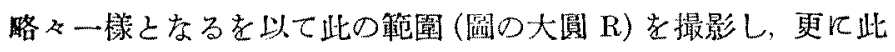
中の乎徑 $1.1 \mathrm{~cm}$ の部分 (小圓 $\mathrm{r}$ ) 它寫訔中に收めたり. $\mathrm{Zn}-\mathrm{Hg}$ の $2.00 \%, 1.00 \%, 0.50 \%$ のもを夫々 A, B, C 之記せん. 酸液 を注ぐ時は注意を要す。然らざれば界面の動擩摩擦により最初 より絊微氣泡の密生し $\mathrm{A}, \mathrm{B}, \mathrm{C}$ 三者の界面の模樣に何等の調和 る見出されざるに至る. 又酸液の濃度大なる程, 氣泡の成長速 かに，之が原因となりて順當に成長せる氣泡の間に細微氣泡の 競ひ生ぜんとする傾向を增すため，寫真撮影の目的に添はさる

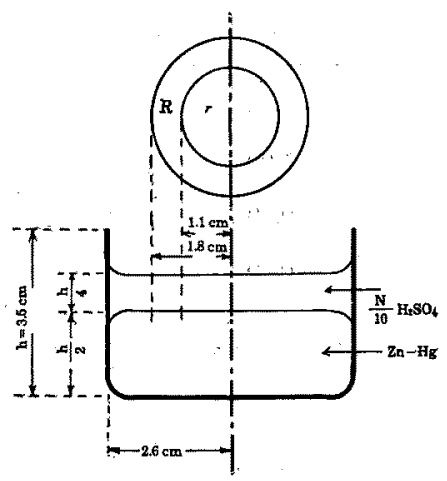
事多し，依りて成るへく氣泡の設生尠く，且つ之が成長に長時

間を要する吙き條件を選ぶを得策とす，是，硫酸の $\frac{\mathrm{N}}{10}$ と云ふが如き稀溚なるるのを探用せる所 以なり。一組の $\mathrm{A} ， \mathrm{~B} ， \mathrm{C}$ は各々の間に五分間を隔つるのみなれば，之等は全く同一の環境に於ける

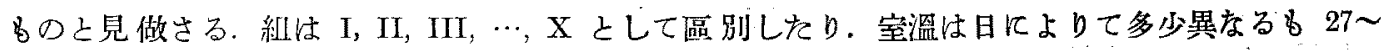
$29.5^{\circ}$ の範園內にあり。

9) 'Beiträge zur Kenntniss der Amalgame der alkalischen Erden, des Zinks und des Cadmiums', Göttingen, 1899. 10) J. Phys. Chem., 14 (1910), 169. 
フマルガムの還元作用に就て（第二報）

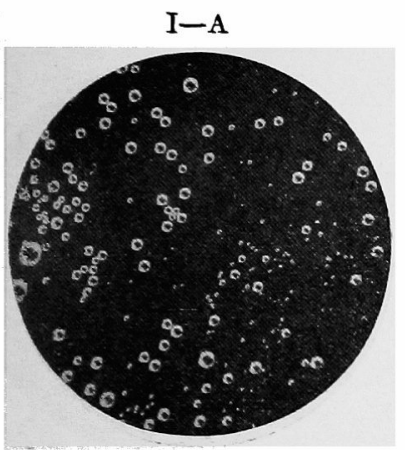

(114)

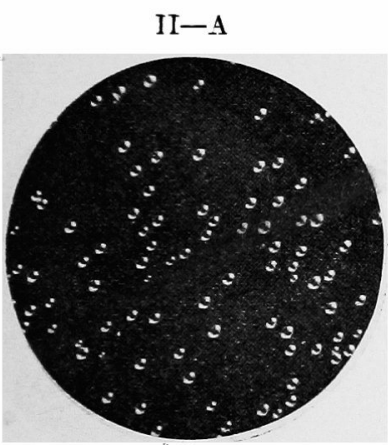

(92)

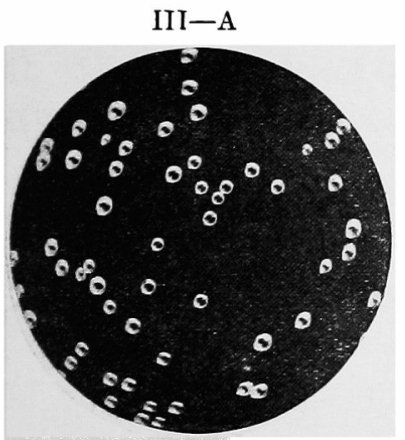

(58)

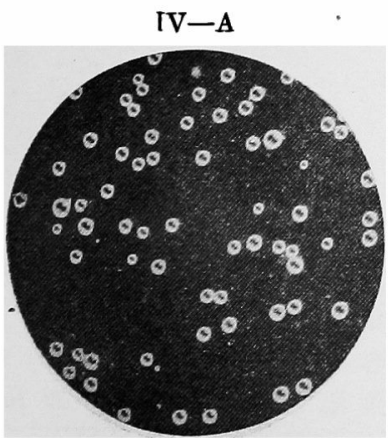

(67)

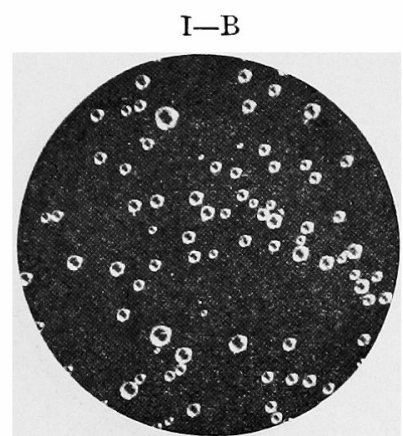

(83)

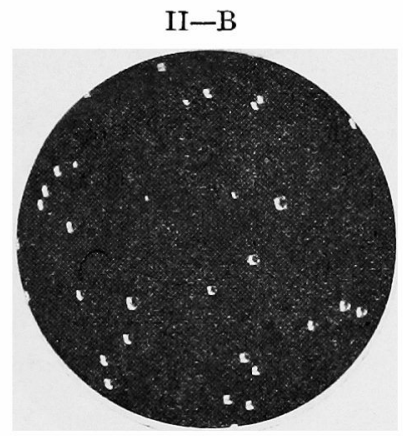

(32)

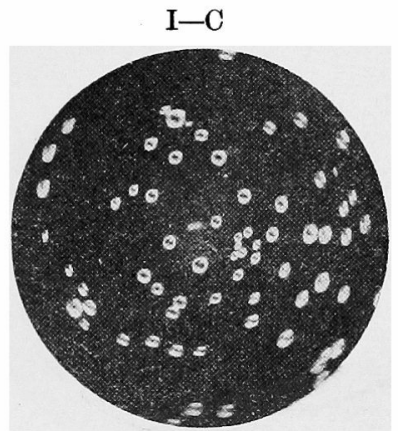

(68)

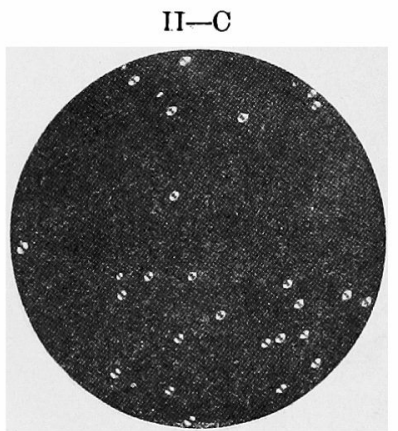

(25)

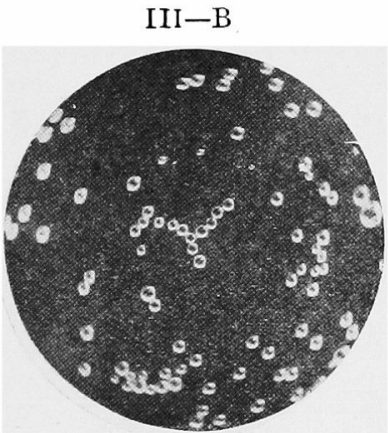

(88)

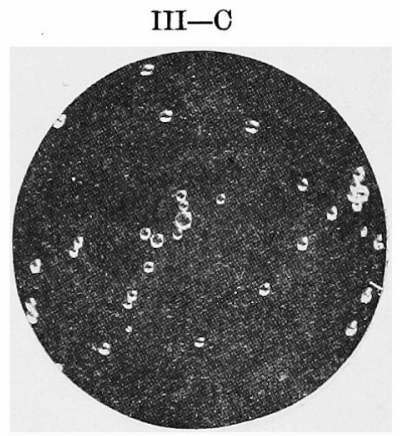

(34)

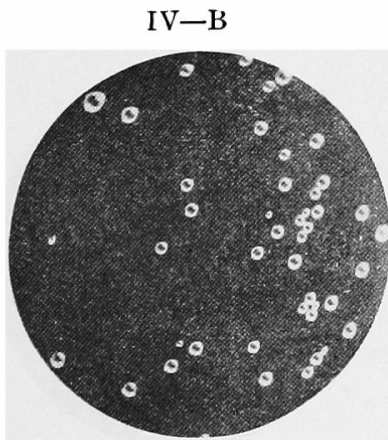

(45)

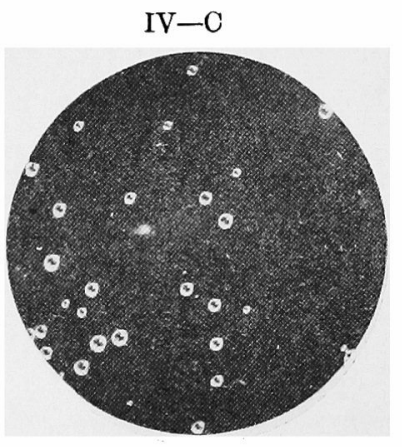

(29) 


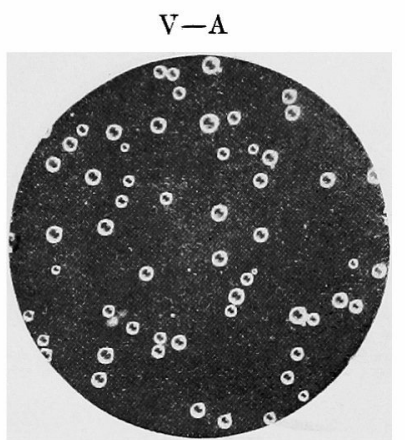

(60)

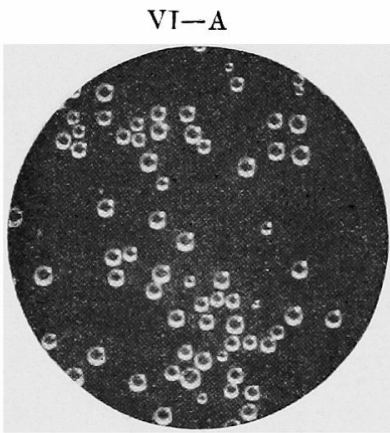

(71)

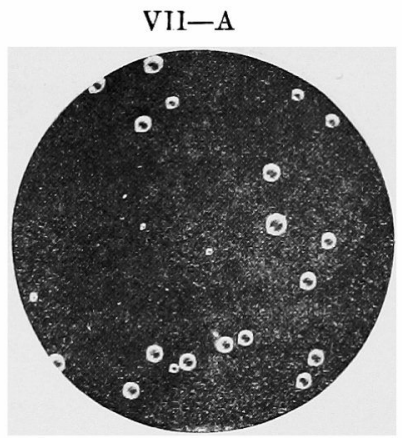

(22)

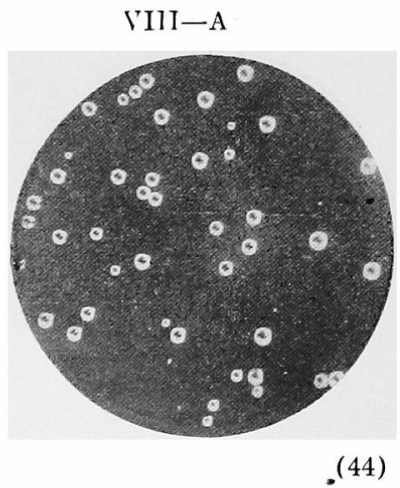

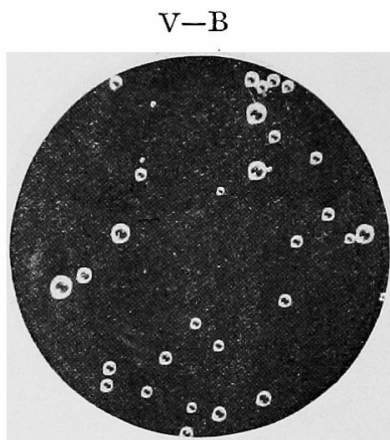

(31)

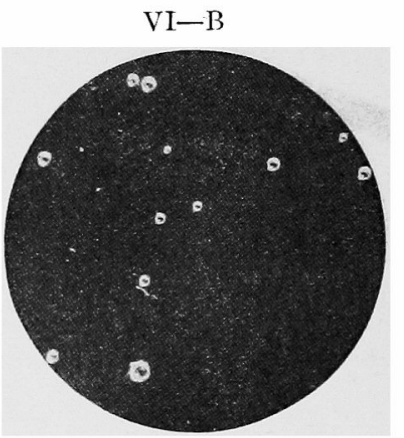

(12)

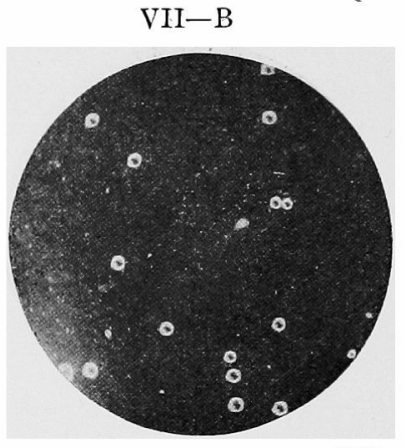

(17)

VIIJ-B

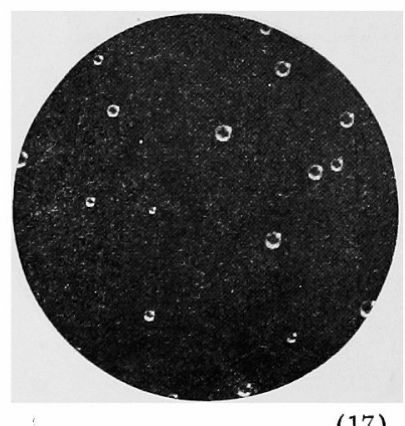

(17)

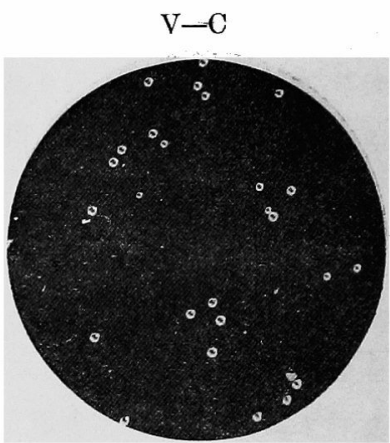

(27)

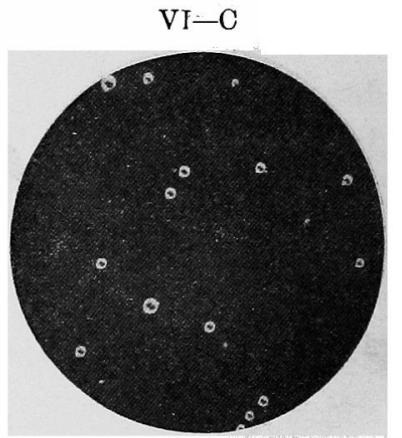

(15)

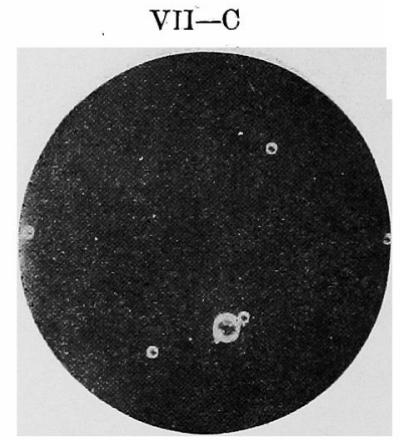

(6) VIII-C

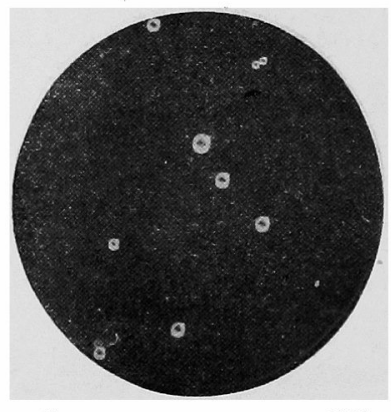

(10) 


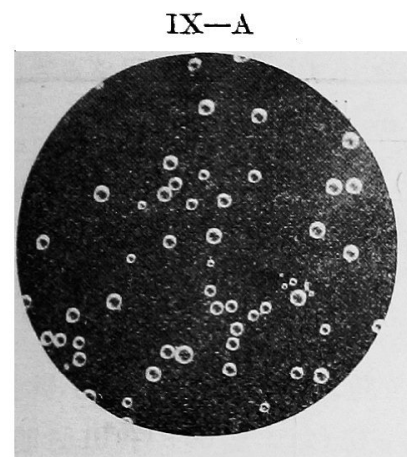

(56)

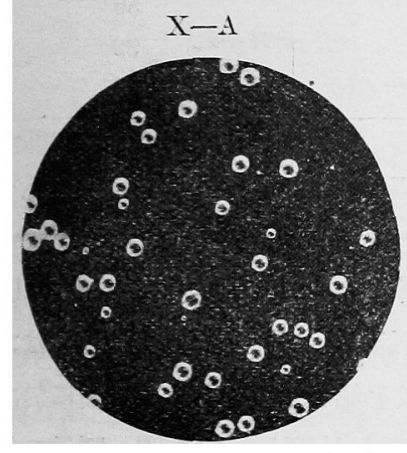

(38)

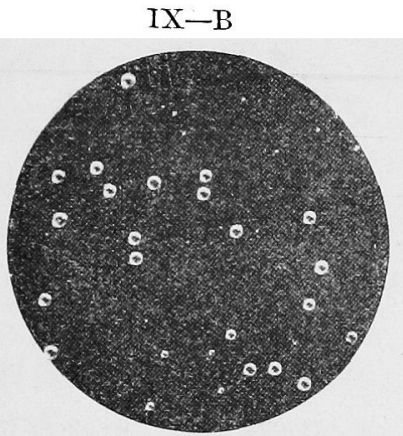

(25)

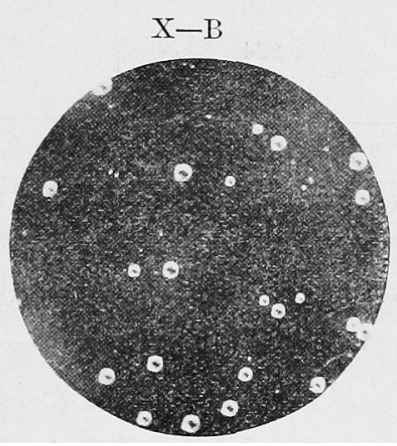

(22)

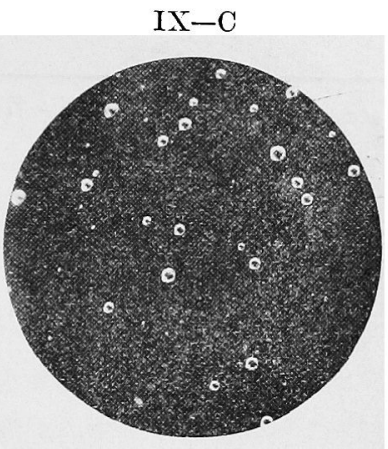

(23)

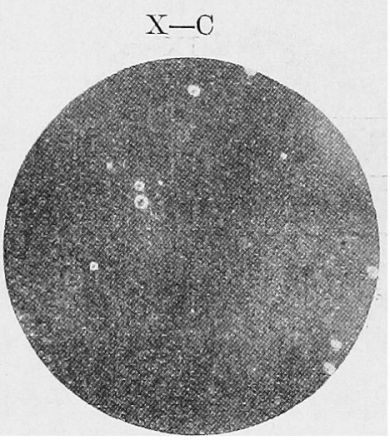

(8)

[丙] 寫椇中の氣泡の計測及び統計

寫㝵飞 II-A，VI一B の如く示したるは前述の區別の第めなり，何下方に括弧を以て園める數字 第 二 表

\begin{tabular}{|c|c|c|c|}
\hline アマルガム名稱 & 氣 & 泡 & -教 \\
\hline 惯驗番號 & $\stackrel{A}{A}$ & $\begin{array}{c}\mathrm{B} \\
(1.00 \%)\end{array}$ & $\begin{array}{c}\mathrm{O} \\
(0.50 \%)\end{array}$ \\
\hline I & 114 & 83 & 68 \\
\hline II & 92 & 32 & 25 \\
\hline III & .58 & 88 & 34 \\
\hline IV & 67 & 45 & 29 \\
\hline r & 60 & 31 & 27 \\
\hline$\therefore$ VI & 71 & 12 & 15 \\
\hline VII & 22 & 17 & 6 \\
\hline VIII & 44 & 17 & 10 \\
\hline$\div$ ix & 56 & 25 & 23 \\
\hline $\mathbf{x}$ & 38 & 22 & 8 \\
\hline 氣泡 數 總 和 & 622 & 372 & $24 \tilde{5}$ \\
\hline $\begin{array}{l}\mathrm{B} \text { を } 100 \text { としたる時の } \mathrm{A}, \mathrm{C} \text { の比篗 } \\
\text { 理論 值よ，可百分 比誤差 }\end{array}$ & $+\frac{167}{5.0 \%}$ & 100 & $\begin{array}{r}66 \\
+4.8 \% \\
\end{array}$ \\
\hline 理 論 & 159 & 100 & 63 \\
\hline
\end{tabular}




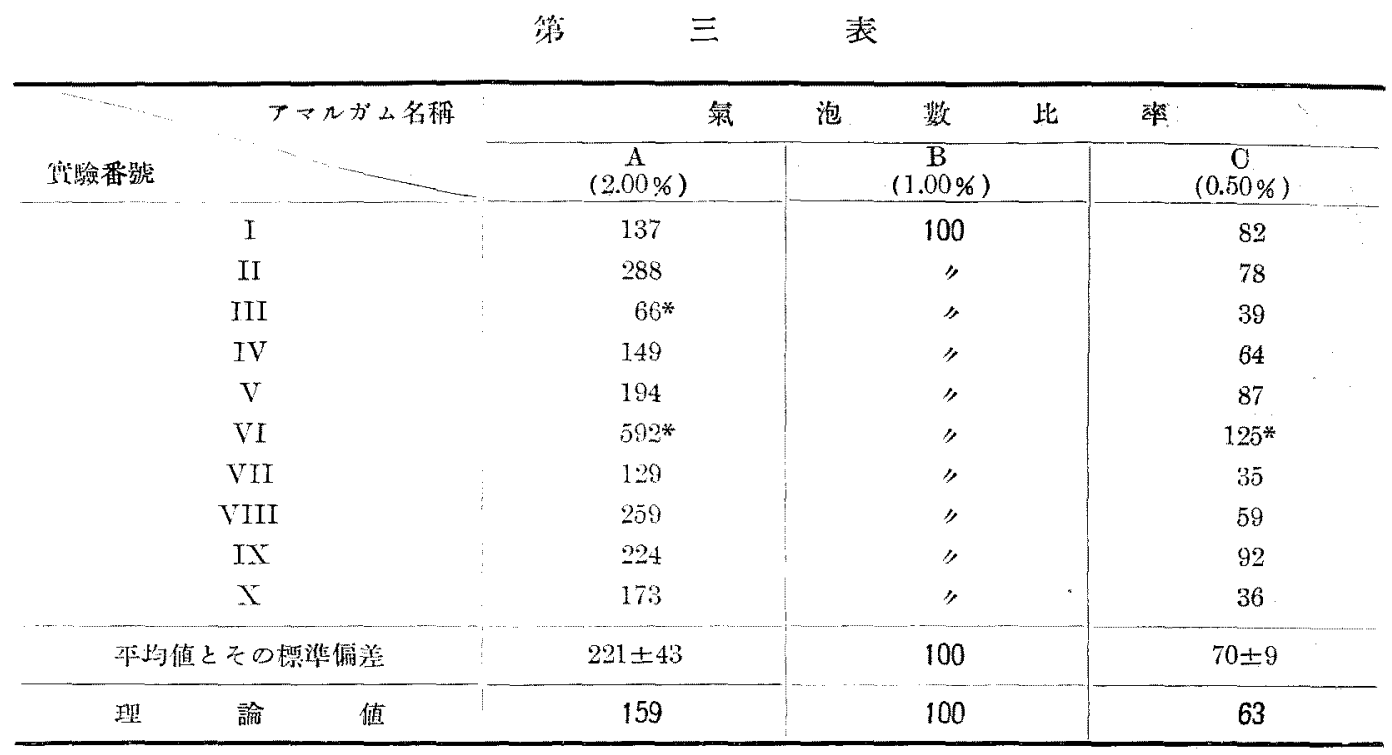

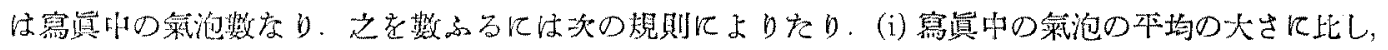

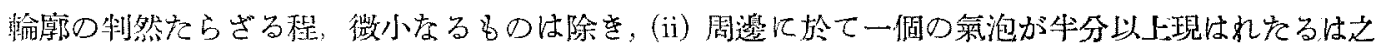
を一個に數へ，牛分以下交るは除く、以上によりて計测したる州泡数考第二表に示す。本表に於て

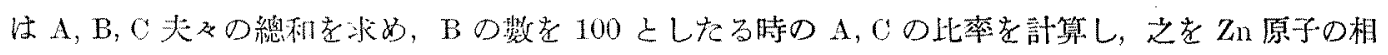

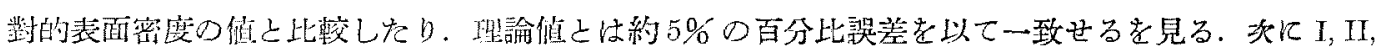

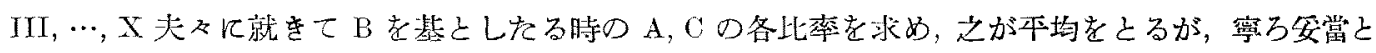

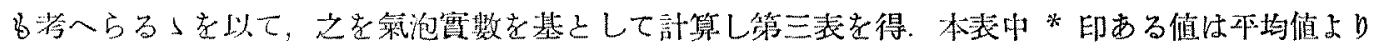

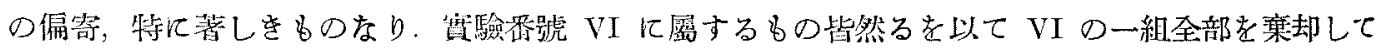

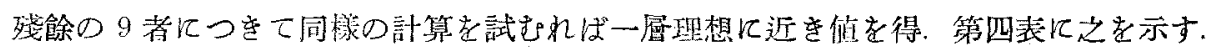

$$
\text { 第四关 }
$$

(置驗番跟 VI を除をむる9者を基としたる計算)

\begin{tabular}{|c|c|c|c|}
\hline アマルがム名稱 & $\begin{array}{c}A \\
(2.00 \%)\end{array}$ & $\begin{array}{c}\mathrm{B} \\
(1.00 \%)\end{array}$ & $\begin{array}{c}\mathrm{C} \\
(0.50 \%)\end{array}$ \\
\hline 比淮の平均值之其の標準偏差” & $173 \pm 22$ & 100 & $64 \pm 7$ \\
\hline 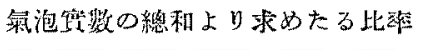 & $\underline{161}$ & 100 & $\underline{64}$ \\
\hline 理論值よりの百分此䛤差 & $+1.3 \%$ & & $+1.6 \%$ \\
\hline 値 & 159 & 100 & 63 \\
\hline
\end{tabular}

\section{[丁] 結果の阽判}

上飞得杞る第四表の結果支以て最媵の洘察に移らんと欲す。（第二表，第三表の結果を以てするも

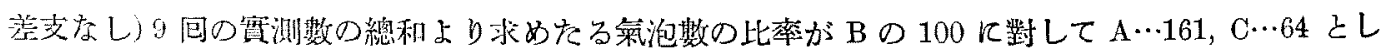


て理論上より要求せらるる數值と $2 \%$ 以下の百分比誤美を以て一致を示せるは，前記所見の大狢贸

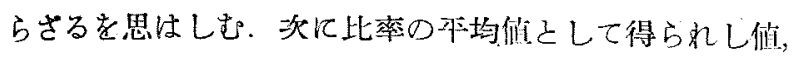

$$
\left\{\begin{array}{l}
A \cdots 173 \pm 22 \\
C \cdots 64 \pm 7
\end{array}\right.
$$

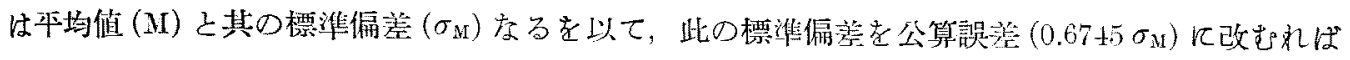

$$
\left\{\begin{array}{l}
A \cdots 173 \pm 14.8 \\
\mathrm{C} \cdots 64 \pm 4.7
\end{array}\right.
$$

を得. 吾人が或る事解に就をての觀测の真の平均倠を知り得るものとせば，此の真の平均值は殆を

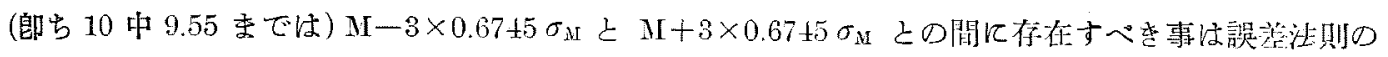

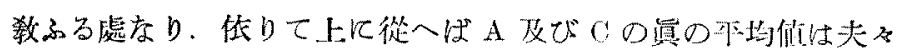

$$
\left\{\begin{array}{l}
A \cdots 128-218 \\
\mathrm{C} \cdots 56-84
\end{array}\right.
$$

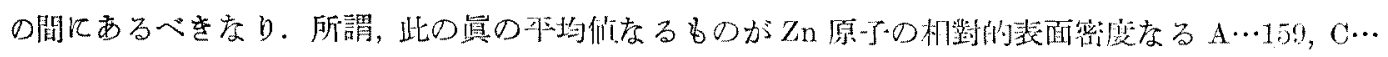

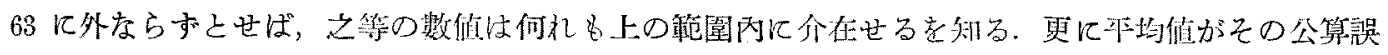

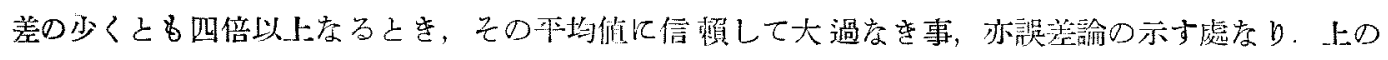

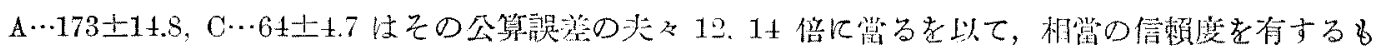

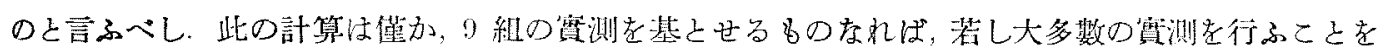

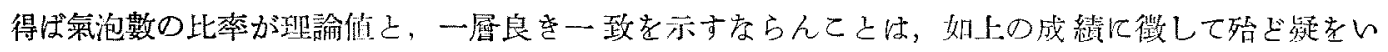
れさる處孛り。

\section{(III) 總括}

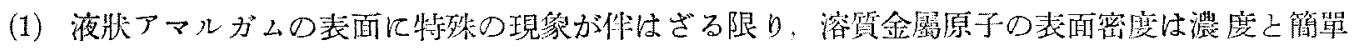
なる關係にあり。

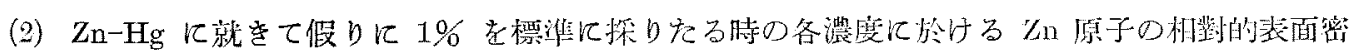
度它計算せり。

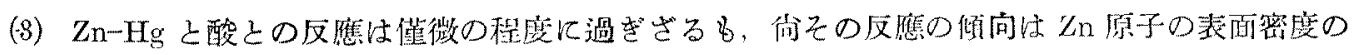
大小に對應す.

（4） $\mathrm{Zn}-\mathrm{Hg}$ と酸との反應の傾向は，一定條件の下に比較せる界面の水素栽泡數によつて代表せら る.

（5）上の水素氣泡數の比と $Z n$ 原子の表面密度の比之䟽計上一致す.

以上は次報の賽驗結果の㳵察に重大孛れば，卦に本研究第二報として報告する次第なり.

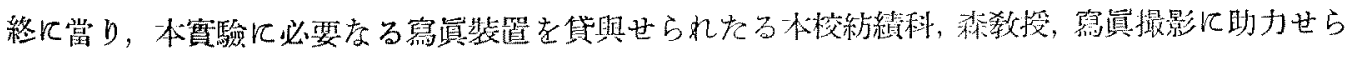
れし金子東助君に感謝す。 